\title{
The Effectiveness of Employee Training on Firm Performance: Evidence from Vietnam
}

\author{
Young-Hee Kang \\ Kyunga Na \\ Business School, Keimyung University \\ Republic of Korea
}

\begin{abstract}
This study aims to test how employee training affects the performance of firms in Vietnam. Despite robust and stable economic growth of Vietnam, little research has been conducted on the effectiveness of human resource development of Vietnamese companies because it is difficult to obtain firm-level data of Vietnam. To fill this gap, using firm-level data, this study analyzes the effects of vocational skills training, managerial/leadership training and interpersonal/communication skills training on firm performance. To this end, this research obtains a final sample of 852 firms from the World Bank Enterprise Survey (WBES) database in 2015 and constructs an ordinary least squares regression to identify the types of employee training program on the sales growth rate. The results show that vocational skills training and managerial/leadership training have significantly positive impact on the sales growth rate.
\end{abstract}

Keywords: Vietnam; human resource development; sales growth rate; managerial/leadership training; vocational training; interpersonal training

\section{Introduction}

This study examines how different types of formal employee training programs affect firm performance in Vietnam. The nation has been regarded as the Post-Crisis-China that it has shown high economic growth rate since the global financial crisis. Until recently, China has been the world's production base as well as the most attractive investment destination due to cheap and abundant labor force and the largest population in the world(Austria 2012). However, China's economic growth has faltered recently while Vietnam's economic growth has been robust. This has increased the attractiveness of Vietnam as an investment destination that can replace China (The Economist 2016). In fact, Vietnam has shown signs of great economic potential: stable inflation, political stability, robust economic growth, abundant young and low-wage workers, increase in foreign direct investment (FDI), and so on (Troung et al. 2010; World Bank 2017; Chae and Lee 2018).

Despite Vietnam's economic potential, there are some obstacles to actually achieving the growth, one of which is the lack of skilled labor force and infrastructure (Binh and Linh 2017; Trounget al. 2010). Investment in labor-intensive industry that utilizes cheap labor force can lead to economic growth to some levels (Truong et al. 2010), which has been the strategy for Vietnam as the production base of labor-intensive segments. However, the industrial structure of Vietnam has been shifting from the labor intensive industry to technology and capital-intensive industry (Truong et al. 2010). Considering the diverse stages of economic development of the ASEAN (Association of Southeast Asian Nations) members, Vietnam could be staying as the production base in the ASEAN region precisely because the country lacks the skilled work force in technology or capital-intensive segments compared to Singapore, Indonesia, and Malaysia.

Furthermore, for economic growth or development, a country needs to foster a skilled labor force through education and training (Montague 2013); the same applies to businesses for them to stay competitive (Montague 2013; Van Tuan and Nguyen 2012; Truong et al. 2010; Zhu et al. 2008).Vietnam lacks a skilled labor force due to its poor educational program, similar to many other emerging markets (Montague 2013). To obtain a more competent workforce, the Vietnamese government has made a great effort on formal education (Barker and Üngör 2018). However, Vietnam's education system has not played a critical role in improving the quality of human resources (Vietnam Ministry of Education and Training 2014). Also, Vietnamese firms have complained of difficulties in finding skilled workers, which is one of the major obstacles to business activities in Vietnam (World Bank 2013). However, there is relatively less empirical research that tests the effects of training on firm performance in Vietnam (e.g., Nguyen et al. 2013; Thang and Quang 2011; Van Tuan and Nguyen 2012). 
The development experience of past Asian Tigers (i.e., Singapore, South Korea, and Taiwan) implies that Vietnam needs more skill-intensive jobs and skilled workers in order to achieve further economic development (Barker and Üngör 2018). To fill the gap in the previous research, this study aims to investigate the effect of human resource development on firm performance. Specifically, this study attempts to identify which type of training has positive effects on sales growth of Vietnamese corporates. There are a variety of training programs to enhance skills, knowledge, and abilities of human resources. This study focuses on training for vocational skills, managerial/leadership skills and interpersonal/communication skills in that they are required ubiquitously across all organizations.

This study would contribute to the existing literature as follows. First, this study is expected to contribute to the literature on human resource development of emerging markets by testing the relationship between employee training and firm performance in Vietnam. There are a significant number of review studies that focus on the characteristics of human resource management (HRM) in Vietnam or the development of HRM related to the progress of Vietnam's economic growth (e.g., Manning 2010; Montague 2013; Nguyen et al. 2018; Thang et al. 2011; Thang and Quang 2007; Truong et al. 2010; Zhu et al. 2007).However, there are few empirical studies that test the effect of employee training on firm performance (e.g., Nguyen et al. 2013; Nguyen et al. 2011; Thang and Quang 2011; Van Tuan and Nguyen 2012). This study will fill this gap by providing empirical evidence of the effectiveness of employee training. Also, this research will contribute to the literature on management in Southeast Asian emerging markets. Southeast Asian transition economies have drawn much attraction as a production base of the global value chain because they have young and large scale population. However, the majority of the literature on the region has dealt with macroeconomic issues or institutional factors that have positive or negative impacts on firm performance (Austria 2012; Barker and Üngör 2018; Chia 2013; Das et al. 2013; OECD 2010) rather than firm characteristics. Using firmlevel data and focusing on a specific aspect of the firms that can influence their performance, the current study will enrich the literature on management in Southeast Asian emerging markets.

In addition, this study will provide practical information to companies considering direct or indirect investment in Vietnam by identifying employee training programs that will improve the productivity of Vietnamese firms. Vietnam is still an attractive investment destination for global businesses. However, as the rush of multinational companies to Vietnam leads to increased competition in Vietnam, concerns about the deterioration in Vietnam's investment profitability has been increasing. Therefore, companies entering Vietnam need to establish a competitive investment strategy.

\section{Literature Review and Theoretical Background}

\subsection{Labor force of Vietnam}

Vietnam has a young and large workforce: around 50 percent of the population is 25 years old or younger (Truong et al. 2010). Since the last decade the country has been especially competitive in the labor-intensive sector because low-wage workers account for a large amount of firm productivity or profitability. However, Vietnam's strategy based on lowwage labor force puts limitations to its economic growth (Troung et al. 2010). Vietnam has suffered from a severe shortage of skilled labor force and competent managers (Binh and Linh 2017; Montague 2013; Troung et al. 2010). Like other South Asian countries, Vietnam has paid a great attention to enhance their vocational education and training systems (Agrawal 2013). However, the education of Vietnam has not attributed to improving the quality of human resources (Vietnam Ministry of Education and Training 2014).

In addition, although the number of specialized workers who are formed by vocational education or training is increasing, it is still not large enough to meet the demand. In all the sectors, the managers are required to upgrade the managerial skills (Swierczek and Anh 2000).However, only 23-30 percent of the labor force has received professional trainings, about one-third of the level expected in transitional economies (Truong et al. 2010) (p. 84).For implementing the FDI projects, Vietnam has hired expatriate workers from Singapore, Thailand, and Malaysia (Truong et al. 2010). Although Vietnam has been considered an attractive investment, the lack of skilled workers has been noted as a weakness (Kwak and Lee 2016: p. 26; US Department 2015).Because Vietnam was incorporated to the global value chain later than Singapore, Indonesia, and Malaysia, it is difficult to ignore the possibility that its role in the ASEAN region would be limited to an assembly production base with low economic added value. To break this role, securing skilled workers will be crucial for the Vietnam.

\subsection{Employee training \& Firm Performance}

Human resources, employees, are regarded as a critical factor of organizational performance. Training and development can contribute to increase the skill flexibility of employees because it helps them learn how to cope with 
changes in technology, markets, and organizational structures (Knoke and Kalleberg 1994). Training has positive effects on firm growth such as enhancing competitive advantages (Fairfield-Sonn 1987) and increasing firm growth (Bartel 1994).

Similarly, Kalleberg and Moody (1994) address that training contributes to improving all aspects of firm performance such as sales growth, market share, and employment relations. Montague (2013: p. 210) also addresses that educated and skilled workforce is likely to promote problem-solving, economic change, and overall productivity. The impact of training on the performance of a company may differ across the type of training. Also, training requires additional costs over the wages, so it is important to identify and select training programs that are more effective in improving firm performance. Among a variety of training, this study focuses on vocational training (job-specific skills or non-IT technical skills), managerial/leadership training and interpersonal/communication skills training because there is a lack of skilled, experienced workers at the managerial position in Vietnam.

\subsection{Vocational Training and Firm Performance}

Vocational skills training means activities that focus on enhancing skills and knowledge required for a certain job or task. Vocational skills include job-specific behaviors and knowledge such as handling of tools and equipment and the relevant processes. Skilled workers are likely to have high levels of job-specific skills, which lead to a better individual performance than unskilled ones. According to human capital theory, human capital can be increased by various activities or experiences that are transferred to knowledge and skills, which leads to enhancing individual productivity. Formal education and job training are regarded as contributing to the growth of human capital. In particular, as the main purpose of vocational training is to improve employees' ability to implement a given job or task, trained employees are more likely to show better job performance than untrained ones. Barron et al. (1999) demonstrates that employee productivity growth is highly correlated to job training. In other words, Vocational training contributes to employees to a better workforce, which has positive effects on firm performance.

Based on the resource-based view (RBV: Barney 2001), skilled, flexible, and well-educated workforce plays a critical role in creating and sustaining competitive advantages (Porter 1990). Competent employees can be a strategic resource in that they are valuable and hard to be replicated. Many studies have reported that competitive advantages come from the development of firm-specific resources such as knowledge, quality, innovation, and human resources linked to business strategy (e.g., Dmitrovic and Zupan 2001; Khandekar and Sharma 2005). As a firm-provided training is likely to be firm-specific, an in-house vocational training would help foster manpower that is necessary to implement the firm's business strategies. Thus, Hypothesis 1 is suggested as follows: Hypothesis 1:In-house vocational training is positively associated with firm performance.

\subsubsection{Managerial/leadership skills Training and Firm Performance}

Managerial/leadership training refers to training for increasing managerial capacity. Managerial/leadership skills training is aimed at improving skills relevant to on-the-job performance (Burke and Day 1986: 232). In general, managerial/leadership training provides knowledge and expertise related to problem solving and decision making, human relations, motivation, and general management (Burke and Day 1986: 232). Managers of an organization are likely to have a huge influence on organizational performance (Bono and Judge 2003; Powell and Yalcin 2010). Managerial/leadership training program can be a good option to obtain competent managers (Burke and Day 1986). Currently, managerial/leadership education is required for success in the market because the global economy requires businesses to cope with technological innovation and severe market competition (Kutschera and Byrd 2005; Saari et al. 1988). In this line, many businesses have paid attention to managerial/leadership training in order to sustain the effectiveness of their managers (Powell and Yalcin 2010).Many studies have mentioned the importance of the investment in managerial/leadership training (e.g., McAlearney 2005; Rausch and Allio 2005). For instance, McAlearney (2005) implies that managerial/leadership training contributes to obtaining a more competent workforce as well as financial benefits (Powell and Yalcin 2010: p. 228). In order for the Vietnamese companies to succeed in the global value chain, they need to enhance their competitiveness through innovation. Firm innovation is positively related to highly-educated managers (Ayyagari et al. 2011). Therefore, hypothesis 2 is suggested as follows: Hypothesis 2: Managerial/ leadership training is positively associated with firm performance.

\subsubsection{Interpersonal/communication skills Training and Firm Performance}

Interpersonal/communication skills refer to a set of basic attitudes required in human relationships (Rogers 1951).Organizational members need good communication skills because they often have to interact with others. Interpersonal relationships at workplace are based on communication. Communication means the understanding of meaning beyond conveying information and idea. 
As no organization operates without sharing information or meaning among its members, communication is one of important factors that influence organizational effectiveness (Robins and Judge 2016).In this line, effective communication plays a critical role in organizational performance. However, there are many barriers to effective communication such as filtering, selective perception, and cultural differences. There is a great amount of the population that suffers from weakening communication apprehension (Schlenker and Leary 1982; Withers and Vernon 2006).

According to Bambacas and Patrickson (2008), some managers lack the ability to convey clear messages, the ability to actively listen, and the ability to motivate their subordinates. Interpersonal/communication skills training aims to improve the ability that help individuals to interact with others at workplace or in business settings. Many studies have provided support for the effectiveness of interpersonal/communication skills training (e.g., Heaven et al. 2006; Wilkinson et al. 2002). Therefore, hypothesis 3 is suggested as follows: Hypothesis 3: Interpersonal/communication skills training is positively associated with firm performance.

\section{Sample and Research Design}

\subsection{Sample}

We obtain a sample from the World Bank Enterprise Surveys (WBES) dataset, which has been collected by the World Bank since the early 2000s. To test the effectiveness of employee training in Vietnam, this study uses the sample of 2015 Vietnam WBES that was implemented between November 2014 and April 2016.After deleting missing values, the final sample consists of 852 Vietnamese firms. Table 1 displays the characteristics of the sample. In terms of industry, there are 616 manufacturing firms (72.3 percent) and 236 service firms (27.7 percent) (see Panel A). In terms of formal training type, the largest group is training not provided (76.17 percent), and followed by training of vocational skills (19.13 percent), interpersonal/communication skills (2.58 percent), and managerial/leadership skills (2.12 percent) (see Panel B). Table 2 also displays the characteristics of the sample. The average firm age is 12.0 years. Large firms of the sample take about 26.5 percent (226) while medium and small-sized firms do 35.21 percent (300 firms) and $326(38.26 \%)$. Finally, 35 firms (4.11 percent) are listed on the stock market and 63 firms (7.39 percent) are subsidiaries of large firms.

Table 1. Sample Distribution.

\begin{tabular}{ccc}
\hline \multicolumn{3}{c}{ Panel A: Sample Distribution by Industry } \\
\hline & Firms & $\%$ \\
\hline Manufacturing industry & 616 & 72.30 \\
Service industry & 236 & 27.70 \\
& & 100.00 \\
\hline Total & 852 &
\end{tabular}

\begin{tabular}{cccc}
\hline \multicolumn{4}{c}{ Panel B: Sample Distribution by Formal Training } \\
\hline & Full Sample & Manufacturing & Service \\
\hline None & $649(76.17 \%)$ & $479(56.22 \%)$ & $170(19.95 \%)$ \\
Managerial and leadership skills & $18(2.12 \%)$ & $11(1.29 \%)$ & $7(0.83 \%)$ \\
Interpersonal and communication skills & $22(2.58 \%)$ & $11(1.29 \%)$ & $11(1.29 \%)$ \\
Vocational or job-specific skills & $163(19.13 \%)$ & $115(13.5 \%)$ & $48(5.63 \%)$ \\
Total & & & $236(27.70 \%)$ \\
\hline
\end{tabular}


Table 2. Characteristics of the Sample

\begin{tabular}{c|ccc}
\hline Category & Full Sample & Manufacturing & Service \\
\hline Ave. Firm age (yrs.) & $12.00(S D=9.88)$ & $12.40(S D=10.45)$ & $10.96(S D$ \\
$=8.14)$ \\
Large size (100+ employees, \%) & $226(26.53 \%)$ & $185(21.72 \%)$ & $41(4.81 \%)$ \\
Medium size (21 <employees $\leq 99, \%)$ & $300(35.21 \%)$ & $222(26.06 \%)$ & $78(9.15 \%)$ \\
Small size (employees $\leq 19, \%)$ & $326(38.26 \%)$ & $209(24.53 \%)$ & $117(13.73 \%)$ \\
Listed on s stock exchange (\%) & $35(4.11 \%)$ & $30(3.52 \%)$ & $5(0.59 \%)$ \\
Subsidiary of large firms (\%) & $63(7.39 \%)$ & $44(5.16 \%)$ & $19(2.23 \%)$ \\
\hline
\end{tabular}

\subsection{Research Design}

The research design examines the effectiveness of employee training on performance of firms in Vietnam using the following regression.

$$
\text { Performance }=\alpha+\beta_{i}(\text { Focus ofTraining })+\sum \text { Control }+\varepsilon(1)
$$

\subsubsection{Dependent Variable (annual sales growth, \%)}

The first model examines whether the formal training programs for a firm's permanent, full-time employees can influence on its performance. This study uses an annual growth rate as a proxy of firm performance. Because it takes time to see the effect of training takes time it is appropriate to measures sales growth rate rather than sales. The sample of this study provides information of past total annual sales from one year and 3 years ago, which results in a two-year gap for the dependent variable, the annual sales growth $(\%)$ calculated as follows:

$$
\text { Annual Sales Growth }=\left(\text { Sales }_{t}-\text { Sales }_{t-2}\right) \div\left(\left(\text { Sales }_{t}+\text { Sales }_{t-2}\right) \div 2\right)
$$

\subsubsection{Test Variables (Focus of Training)}

The test variable is the type of formal training for the firm's permanent, full-time employees that affects firm performance. The test variable is a categorical variable representing the primary focus of training as follows:

\section{No formal training}

Vocational skills training

\section{Managerial/leadership skills training}

Interpersonal/communication skills training

Also, the test variable is measured as a dummy variable (one if a certain training program is provided and zero otherwise). Any formal training programs used by less than 10 firms are excluded from the sample.

\subsubsection{Control Variables (Control)}

The control variables are firm size, firm age, proportion of export, proportion of external financing, listing status, subsidiary status, and industry dummies. The detailed explanations are as follows.

Size_large: One if the number of full time employees is equal to or greater than 100 and zero otherwise.

Size_medium: One if the number of full time employees is between 20 and 99, and zero otherwise.

Firm age: Natural logarithm firm age

Export: percentage of export from sales

External finance: percentage of external financing

Listing status: One if a firm is publicly listed and zero otherwise.

Subsidiary: One if a firm is a part of a larger firm and zero otherwise.

Industry_Manufacturing: One for firms in manufacturing industry and zero for those in service industry.

\section{Results}

\subsection{Descriptive Statistics \& Pearson Correlations}

Table 3 presents the mean and standard deviation of each variable as well as the Pearson correlations between model variables in Equation 1. The proxy for firm performance, Annual growth rateis positively correlated with Export $(r=$ $0.06, p<.10)$ and Industry_Manufacturig $(r=0.12, p<.01)$. In contrast,Annual growth rate is negatively correlated with No formal training $(r=-0.07, p<0.05)$, Size_medium $(r=-0.06, p<.10)$, andFirm age $(r=-0.13, p<.01)$. 
Table 3. Statistics and Pearson correlation matrix $(N=852)$.

\begin{tabular}{|c|c|c|c|c|c|c|c|c|c|c|c|c|c|c|c|c|}
\hline $\begin{array}{l}\mathrm{N} \\
\mathrm{o} .\end{array}$ & Variable & $\begin{array}{l}\text { Me } \\
\text { an }\end{array}$ & $\begin{array}{l}S \\
D\end{array}$ & 1 & 2 & 3 & 4 & 5 & 6 & 7 & 8 & 9 & 10 & 11 & 12 & 13 \\
\hline 1. & $\begin{array}{l}\text { Annual growth } \\
\text { rate }\end{array}$ & $\begin{array}{l}0.1 \\
1\end{array}$ & $\begin{array}{l}0 . \\
56\end{array}$ & 1.00 & & & & & & & & & & & & \\
\hline 2. & $\begin{array}{l}\text { No formal - } \\
\text { training }\end{array}$ & $\begin{array}{l}0.7 \\
6\end{array}$ & $\begin{array}{l}0 . \\
43\end{array}$ & $\begin{array}{l}- \\
0.07\end{array}$ & 1.00 & & & & & & & & & & & \\
\hline 3. & $\begin{array}{l}\text { Managerial/ } \\
\text { leadership }\end{array}$ & $\begin{array}{l}0.0 \\
2\end{array}$ & $\begin{array}{l}0 . \\
14\end{array}$ & 0.05 & $\begin{array}{l}- \\
0.26\end{array}$ & 1.00 & & & & & & & & & & \\
\hline 4. & $\begin{array}{l}\text { Interpersonal/Com } \\
\text { munication }\end{array}$ & $\begin{array}{l}0.0 \\
3\end{array}$ & $\begin{array}{l}0 . \\
16\end{array}$ & 0.01 & $\begin{array}{l}- \\
0.29\end{array}$ & $\begin{array}{l}- \\
0.02\end{array}$ & $\begin{array}{l}1.0 \\
0\end{array}$ & & & & & & & & & \\
\hline 5. & Vocational & $\begin{array}{l}0.1 \\
9\end{array}$ & $\begin{array}{l}0 . \\
39\end{array}$ & 0.05 & $\begin{array}{l}- \\
0.87 \\
* * * *\end{array}$ & $\begin{array}{l}- \\
0.07\end{array}$ & $\begin{array}{l}- \\
0.0 \\
8^{* * *}\end{array}$ & 1.00 & & & & & & & & \\
\hline 6. & Size_large & $\begin{array}{l}0.2 \\
7\end{array}$ & $\begin{array}{l}0 . \\
44\end{array}$ & 0.02 & $\begin{array}{l}- \\
0.19\end{array}$ & ${ }_{* * * *}^{0.12}$ & $\begin{array}{l}0.0 \\
2\end{array}$ & 0.16 & 1.00 & & & & & & & \\
\hline 7. & Size_medium & $\begin{array}{l}0.3 \\
5\end{array}$ & $\begin{array}{l}0 . \\
48\end{array}$ & $\begin{array}{l}- \\
0.06\end{array}$ & 0.04 & 0.01 & $\begin{array}{l}0.0 \\
0\end{array}$ & $-\overline{0.05}$ & $\begin{array}{l}- \\
0.44 \\
* * * *\end{array}$ & 1.00 & & & & & & \\
\hline 8. & Firm age & $\begin{array}{l}2.3 \\
8\end{array}$ & $\begin{array}{l}0 . \\
59\end{array}$ & $\begin{array}{l}- \\
0.13 \\
* * * *\end{array}$ & $\begin{array}{l}- \\
0.09 \\
* * *\end{array}$ & $\underset{* * * *}{0.11}$ & $\begin{array}{l}0.0 \\
1\end{array}$ & 0.06 & ${ }_{* * *}^{0.25}$ & 0.04 & 1.00 & & & & & \\
\hline 9. & Export & $\begin{array}{l}0.1 \\
7\end{array}$ & $\begin{array}{l}0 . \\
33\end{array}$ & 0.06 & $\begin{array}{l}- \\
0.05\end{array}$ & 0.03 & $\begin{array}{l}- \\
0.0 \\
6^{*}\end{array}$ & ${ }_{* *}^{0.07}$ & ${ }_{* * *}^{0.29}$ & $-\overline{0.05}$ & 0.05 & 1.00 & & & & \\
\hline $\begin{array}{l}1 \\
0 .\end{array}$ & External finance & $\begin{array}{l}0.2 \\
8\end{array}$ & $\begin{array}{l}0 . \\
33\end{array}$ & 0.03 & $\begin{array}{l}- \\
0.12\end{array}$ & 0.03 & $\begin{array}{l}0.0 \\
5\end{array}$ & $\underset{* * * * 10}{0.10}$ & $\underset{* * *}{0.10}$ & 0.03 & 0.09 & 0.04 & $\begin{array}{l}1.0 \\
0\end{array}$ & & & \\
\hline $\begin{array}{l}1 \\
1 .\end{array}$ & Listing status & $\begin{array}{l}0.0 \\
4\end{array}$ & $\begin{array}{l}0 . \\
20\end{array}$ & - & $\begin{array}{l}- \\
0.06\end{array}$ & ${ }_{* * * *}^{0.09}$ & $\begin{array}{l}0.0 \\
0\end{array}$ & 0.03 & $\underset{* * *}{0.24}$ & $-\overline{0.09}$ & $\underset{* * * 2}{0.29}$ & 0.07 & $\begin{array}{l}- \\
0.0 \\
1\end{array}$ & 1.00 & & \\
\hline $\begin{array}{l}1 \\
2 .\end{array}$ & Subsidiary & $\begin{array}{l}0.0 \\
7\end{array}$ & $\begin{array}{l}0 . \\
26\end{array}$ & $\begin{array}{l}- \\
0.02\end{array}$ & - & ${ }_{* * *}^{0.08}$ & $\begin{array}{l}0.0 \\
1\end{array}$ & $\begin{array}{l}- \\
0.01\end{array}$ & ${ }_{* * *}^{0.20}$ & - & $\underset{* * *}{0.14}$ & 0.04 & $\begin{array}{l}- \\
0.0 \\
7^{*}\end{array}$ & 0.35 & $\begin{array}{l}1 . \\
00\end{array}$ & \\
\hline $\begin{array}{l}1 \\
3 .\end{array}$ & $\begin{array}{l}\text { Industry_Manufac } \\
\text { turing }\end{array}$ & $\begin{array}{l}0.7 \\
2\end{array}$ & $\begin{array}{l}0 . \\
45\end{array}$ & $\underset{* * *}{0.12}$ & 0.06 & - & $\begin{array}{l}- \\
0.0 \\
8^{* * *}\end{array}$ & - & $\underset{* * *}{0.13}$ & 0.03 & 0.06 & 0.25 & $\begin{array}{l}- \\
0.0 \\
3\end{array}$ & 0.06 & $\begin{array}{l}- \\
0 . \\
02\end{array}$ & $\begin{array}{l}1 . \\
00\end{array}$ \\
\hline
\end{tabular}

Note: $* p<.10 ; * * p<.05 ; * * * p<.01$.

4.2. Regression Results

Table 4 provides the results of the regression to test the effect of employee training on sales growth rate. Vocational skills training is positively related to annual sales growth $(\beta=0.09, \mathrm{p}<0.1)$, which is marginally significant $(t$-value $=$ 1.95). This means that firms providing vocational skills training are likely to show increase in sales. Therefore, Hypothesis 1 is supported. Also, Managerial/leadership skills training is positive and significant, $\beta=0.11, \mathrm{p}<0.05$ (twotailed). Therefore, Hypothesis 2 is supported. In other words, firms with managerial and leadership training are more likely to increase sales growth than firms that do not provide any training. The coefficient estimate on Interpersonal/communication skills training is positive, but is not significant. Therefore, Hypothesis 3 is not supported. In terms of control variables, Firm age negatively affects sales growth, the coefficient estimate being -0.14 at the 0.01 percent level. Industry_Manufacturing is positively related to sales growth rate $(\beta=0.16, \mathrm{p}<0.01)$. The other control variables do not have a significant effect to sales growth rate. 
Table 4. Results $(N=852)$.

\begin{tabular}{lll}
\hline Variable & Coefficient & $\boldsymbol{t}$-stat \\
\hline Intercept & 0.31 & $3.40^{* * *}$ \\
Test Variables & & \\
Vocational skills & 0.09 & $1.95^{*}$ \\
Managerial/leadership skills & 0.11 & $2.04^{* *}$ \\
Interpersonal/communication skills & 0.28 & 0.88 \\
Control Variable & & \\
Size_large & -0.02 & -0.41 \\
Size_medium & -0.08 & $-1.66^{*}$ \\
Firm age & -0.14 & $-3.97^{* * *}$ \\
Export & 0.06 & 0.91 \\
External finance & 0.07 & 1.18 \\
Listing status & 0.00 & 0.00 \\
Subsidiary & -0.01 & -0.10 \\
Industry_Manufacturing & 0.16 & $3.67^{* * *}$ \\
Adj. R & $3.47 \%$ & \\
N & 852 & \\
VIF (Max = Size_large) & 1.65 & \\
\hline
\end{tabular}

Note1: In Table 4, the following ordinary regression is estimated. Performance $=\alpha+\beta_{\mathrm{i}}($ Focus ofTraining $)+\sum$ Control $+\varepsilon$. The dependent variable, firm performance, is proxied by an annual sales growth (\%). The test variable is a categorical variable representing the type of training: Vocation (Non-IT technical skills, vocational, or job-specific) skills; Managerial/leadership skills; Interpersonal/communication skills; No formal training, and the reference group is "No formal training". The control variables are firm size, firm age, proportion of export, proportion of external financing, listing status, subsidiary status, and industry dummies. The dependent variable is winsorized at the top and bottom $1 \%$.

Note2:*, **, and ***indicate the significance based on $p$-value of less than the 10 percent level, 5 percent level and 1 percent level (two-tailed), respectively.Note3: To mitigate heteroscedasticity and firm clustering effects, robust standard errors are used (Peterson 2009).

\subsection{Additional Analyses}

As Vietnam has played a critical role in the global value chain as a production base, it has been considered to have more competitive advantage in the manufacturing industry than the service industry. To gain further understanding of the effectiveness of in-house training in Vietnam, it might be necessary to test the industrial effects of employee training. Therefore, we have conducted additional analyses to investigate industrial differences in the effect of training on firm performance. Table 5 provides the results of the additional analyses. For manufacturing firms, Managerial/leadership skills training is positive and significant at the 0.01 percent level (two-tailed). For service companies, however, there is no significant relationship between training and annual sales growth. 
Table 5. Results

\begin{tabular}{|c|c|c|c|c|}
\hline & \multicolumn{2}{|c|}{ Manufacturing } & \multicolumn{2}{|l|}{ Service } \\
\hline Variable & Coefficient & $t$-stat & Coefficient & $t$-stat \\
\hline Intercept & 0.49 & $4.86^{* * * w^{*}}$ & 0.17 & 1.15 \\
\hline \multicolumn{5}{|l|}{ Test Variables } \\
\hline Vocational skills & 0.09 & 1.55 & 0.11 & 1.15 \\
\hline Managerial/leadership skills & 0.41 & $2.72^{* * * *}$ & -0.01 & -0.03 \\
\hline $\begin{array}{l}\text { Interpersonal/communication } \\
\text { skills }\end{array}$ & 0.01 & 0.07 & 0.18 & 1.07 \\
\hline \multicolumn{5}{|l|}{ Control Variable } \\
\hline Size_large & 0.00 & -0.07 & -0.08 & -0.68 \\
\hline Size_medium & -0.09 & -1.53 & -0.06 & -0.79 \\
\hline Firm age & -0.15 & $-3.70^{* * *}$ & -0.06 & -1.03 \\
\hline Export & 0.03 & 0.50 & 0.11 & 0.49 \\
\hline External finance & 0.09 & 1.42 & 0.00 & -0.04 \\
\hline Listing status & -0.06 & -0.57 & 0.20 & 1.25 \\
\hline Subsidiary & 0.11 & 1.15 & -0.27 & $-1.91^{*}$ \\
\hline Adj. $R^{2}$ & $3.08 \%$ & & $0.00 \%$ & \\
\hline $\mathrm{N}$ & 616 & & 236 & \\
\hline $\operatorname{VIF}(\operatorname{Max}=$ Size_large $)$ & 1.75 & & 1.37 & \\
\hline
\end{tabular}

Note1: In Table 5 , the following ordinary regression is estimated. Performance $=\alpha+\beta_{\mathrm{i}}($ Focus of Training $)+\sum$ Control $+\varepsilon$. The dependent variable, firm performance, is proxied by an annual sales growth $(\%)$. The test variable is a categorical variable representing the type of training: : Vocation (Non-IT technical skills, vocational, or job-specific) skills; Managerial/leadership skills; Interpersonal/communication skills; No formal training, and the reference group is "No formal training".

The control variables are firm size, firm age, proportion of export, proportion of external financing, listing status, subsidiary status, and industry dummies. The dependent variable iswinsorized at the top and bottom $1 \%$.

Note2:*, **, and ***indicate the significance based on $p$-value of less than the 10 percent level, 5 percent level and 1 percent level (two-tailed), respectively.Note3: To mitigate heteroscedasti city and firm clustering effects, robust standard errors are used (Peterson 2009).

\section{Discussion}

This study aims to investigate the effect of employee training on firm performance in Vietnam. Specifically, this study explores the impact of training of vocational skills, managerial/leadership skills and interpersonal/communication skills on sales growth rate. The ordinary least regression results provide support for the effectiveness of in-house vocational training. This implies that job-specific training is positively associated with firm performance, which is consistent with the literature of human capital theory and RBV. Also, managerial/leadership training is positively associated with firm performance, which supports the existing research that addresses the importance of leadership training (e.g., McAlearney 2005; Rausch and Allio 2005). This result contributes to literature on Southeast Asian emerging markets by showing the positive effects of managerial/leadership training on annual sales growth in Vietnam.

On the other hand, interpersonal/communication skills training does not have a significant impact on sales growth rate. There are some possible reasons as to why interpersonal/communication skills training is not significant to sales growth. First, one explanation may be the characteristics of the sample. Only 11 firms of the sample provide training for interpersonal/communication skills. If this paper used a different sample - one with more firms providing formal training for interpersonal/communication skills - the results could have been significant.

Another potential explanation for the insignificance of the interpersonal/communication skills training might be the gap between the potential and effective ability of an individual in the workplace. Training transfer refers to "the degree to which trainees effectively apply the knowledge, skills and attitudes gained in a training context to the job" (Baldwin and Ford 1988: p. 41). In terms of interpersonal/communication skills training, even though trainees have the knowledge of interpersonal/communication skills, they might not be able to apply it to the job context for reasons such as personality and working environment. Similarly, it takes time to transfer training to organizational performance. 
Training helps accumulate human capital by increasing employees' knowledge and skills, but it takes time for the employees to actually begin applying their new abilities.

The findings of this study enrich the existing literature on HRM and firm performance in Vietnam. As mentioned above, there is lack of empirical evidence of the effectiveness of employee training in the Vietnamese context (Nguyen et al. 2018). Many scholars and policy makers pay attention to the economic growth of transitional economies through the improvement of business performance. However, there are many limitations to the research on firm performance because it is difficult to connect or obtain information on firm-level business activities in emerging markets such as Vietnam. Using firm-level data, this research provides empirical evidence that employee training can improve productivity in Vietnam.

Similarly, this research makes contributions to the literature on management in Southeast Asian emerging regions. Existing ASEAN-related studies take a macro-perspective approach, focusing on the national and social factors(Austria 2012; Barker and Üngör 2018; Chia 2013; Das et al. 2013; OECD 2010), and there is little research performed at the firm level. This study fills the gap by identifying the training programs that improve the firm performance in Vietnam. Moreover, existing research on training in Vietnam has been conducted based on self-reported manager surveys (e.g., Thang and Quang 2005) or highly limited samples (e.g., Binh and Linh 2017). For example, Thang and Quang (2005) define firm performance as managers' perception in the effectiveness, which is a psychological variable rather a fiscal variable. This approach provides limited information of the effects of employee training on firm performance. This study enriches the literature by using a nation-wide sample and firm-level training measures in Vietnam.

The findings of this study provides implications for global businesses entering Vietnam by providing information on training programs that can contribute to firm performance in the Vietnam market. For example, the results show that firm-specific vocational training can have positive effects on firm performance. This means that businesses need to consider providing vocational or firm-specific skills training in order to improve their performance in Vietnam. Also, employers or businesses in Vietnam might provide their employees formal training of leadership skills. In emerging there are lacks of managers and skilled employees. Like other transitional economy Vietnam has suffered from the lack of experienced workers who can be managers. Therefore, it might be necessary that companies provide formal training of managerial and leadership in Vietnam.

In addition, the findings from this study imply that in Vietnam, HRM managers might put more emphasis on vocational skills training and managerial/leadership training than interpersonal/communication skills training. As the budget of training is limited, it is necessary to select training programs that are more effective for corporate performance. This is especially true in emerging markets. According to Agrawal(2013: p.15) vocational education and training (VET) systems have not been working in the South Asian region because the VET stream is small in the region, which also applies to Vietnam. This implies that employers need to pay a great attention to providing more effective training program in Vietnam.

Despite the contribution of this study mentioned above, there are some limitations when interpreting the result. This study focuses on manufacturing firms in Vietnam, which may make the results inapplicable to other industries or emerging economies. Future research could address part of this issue by extending the methodology to other Asian emerging economies such as Indonesia and Thailand. It would be also interesting to explore whether the effect of human resource development on firm performance differs across the countries. For example, one could compare the effectiveness of employee training between transitional economies and advanced ones. Also, future research could be conducted on other industries such as service and information technology (IT).

In addition, the major variables of this study are binary. For a deeper understanding of research question, future research should seek a variety of information by using in-depth interviews or more structured surveys (Lee and Weng 2013: p. 1484). Furthermore, a longitudinal study could be performed to identify the long-term effect of employee training on firm performance because it takes time for the effect of employee training to show. Also, it might be necessary to investigate the effects of training on individual performance or employee motivation (Meyer and Allen 1991). Employee training will ultimately affect sales, but there may be less direct impacts. The effect of training can influence employees' attitude toward their job such as job involvement and job enthusiasm. Especially in emerging markets, there are not enough educational institutions to provide individuals opportunities for education. Employees in Vietnam have very few opportunities to accumulate general or special skills. According to Zhu and Verstraetan(2013), less than 20 percent of manual workers receive training once a year, while only a half of the labor force receives training once a yearin Vietnam. This implies that employees might regard training as benefits or favors provided by the companies they work for (Chambel and Sobral 2011).According to the principle of reciprocity, employees might seek 
to compensate this favor by increasing organizational commitment or job commitment. Therefore, it will be necessary to study the effects of employee training on individual level outcomes. Future research needs to be conducted on effects of Vietnam's institutional characteristics on the relationship between training and firm performance. For example, the effectiveness of in-house training is affected by the education system of the country where a business operates. It needs to identify cultural or societal factors that contribute to enhancing the training effect.

Also, the way and situation in which training is conducted can affect the effectiveness of training. In order to improve the training transfer, trainees should be well-prepared and ready to receive training, and the company should conduct training based on their characteristics. The effectiveness of employee training may vary depending on the training period, training frequency, and pedagogy. Therefore, future research needs to be conducted on how the structure of training influences training performance in emerging markets, particularly Southeast Asian emerging markets.

Conflicts of Interest: The authors declare no conflict of interest.

\section{References}

Agrawal, T.(2013). Vocational education and training programs (VET): An Asian perspective. Asia-Pacific Journal of Cooperative Education, 14, 15-26.

Asian Development Bank. (2018). Asian Development Outlook 2018: How Technology Affects Jobs.

Austria, M. S. (2012). Moving towards an ASEAN economic community.East Asia, 29, 141-156.

Ayyagari.M., Demirgüç-Kunt, A., \&Maksimovic, V. (2011). Firm innovation in emerging markets: the role of finance, governance, and competition.Journal of Financial and Quantitative Analysis,46, 1545-1580.

Baldwin, T. T., \&Kevin Ford, J. (1988).Transfer of training: A review and directions for future research. Personnel Psychology, 41, 63-105.

Bambacas, M., \&Patrickson, M. (2008).Interpersonal communication skills that enhance organisational commitment. Journal of Communication Management, 12, 51-72.

Barker, T., \&Üngör, M.(2018). Vietnam: The Next Asian Tiger? The North American Journal of Economics and Finance, 47, 96-118.

Barney, J. B. (2001). Resource-based theories of competitive advantage: A ten year retrospective on the resource-based view. Journal of Management, 27, 643-650.

Barron, J. M., Berger, M. C., \& Black, D. A.(1999).Do workers pay for on-the-job training? Journal of Human Resources,34, 235-252.

Bartel, A. P. (1994). Productivity record from the implementation of employee training programs.Industrial Relations,33, 411-425.

Binh, T.T. C., \&ManhLinh, N. (2017). Human Resource Management for Innovation in Vietnam's Electronics Industry. Asian Journal of Technology Innovation25(2): 345-366.

Bono, J.E., \& Judge, T.A.(2003).Self-concordance at work: Toward understanding the motivational effects of transformational leaders. Academy of Management Journal, 46, 554-571.

Burke, M.J., \& Day, R.R. (1986).A cumulative study of the effectiveness of managerial training. Journal of applied Psychology, 71, $232-245$.

Chambel, J.M., \&Sobral, F.(2011). Training is an investment with return in temporary workers: a social exchange perspective. Career Development International,16, 161-177.

Chae, S., \&Lee, H. (2018). Vietnam in 2017: The situations and prospects of economics, politics, and internal relations. Journal of Southeast Asian Studies,28, 21-51.

Chia, S. Y. (2014).The ASEAN Economic Community: progress, challenges, and prospects. A World Trade Organization for the 21st Century. ADBI Working Paper440, Asian Development Bank Institute. [Online] Available: http://www.econstor.eu/bitstream/10419/101189/1 /770509193.pdf (March 2, 2019).

Das, S.B., Menon, J., Severino, R., \&Shrestha, O.(Eds.).(2013). The ASEAN economic community: A work in progress (Vol. 14), Singapore: Institute of Southeast Asian Studies.

Dmitrovic, T., \&Zupan, N.(2001).The consistency of human resource management and competitiveness policy in Slovenian companies. South-East Europe Review 3: 19-38. [Online] Available: http://s3.amazonaws.com/zanran_storage/www.boeckler.de/ContentPages/1767936247.pdf\#page=21 (May 10, 2019).

Fairfield-Sonn, J. W. (1987). A strategic process model for small business training and development.Journal of Small Business Management,25, 11-18. 
Heaven, C., Clegg, J., \&Maguire, P.(2006).Transfer of communication skills training from workshop to workplace: the impact of clinical supervision. Patient education and counseling,60, 313-325.

Kalleberg, A.L., \& Moody, J.W.(1994).Human resource management and organizational performance. The American Behavioral,37, 948-962.

Khandekar, A., \& Sharma, A. (2005). Managing human resources capabilities for sustainable competitive advantage: An empirical analysis from Indian global organisations. Education + Training,47, 628-39.

Knoke, D., \&Kalleberg, A.L. (1994).Job training in US organizations.American SociologicalReview, 59, 537-546.

Khandekar, A., \&Sharma, A. (1994).Job training in US organizations.American Sociological Review,59, 537-546.

Kutschera, I., \& Byrd, J.T.(2005).Applying the concept of cognitive continuum to leadership training. Journal of American Academy of Business, 6, 20-25.

Kwak, S., \& Lee, J.(2016).Overseas Expansion Strategy of Major Countries' Firms toward Viet Nam and the Implications for Korea.Policy References 16-02, Sejong: Korea Institute Economic Policy.

Rogers, C. R. (1951). Client-centered therapy: Its current practice, implications, and theory, Boston:Houghton Mifflin.

Manning, C. (2010). Globalization and labour markets in boom and crisis: The case of Vietnam. ASEAN Economic Bulletin,27, 136-157.

McAlearney, A. S. (2005). Exploring mentoring and leadership development in health care organizations: Experience and opportunities. Career Development International, 10, 493-511.

Meyer, J. P., \& Allen, N. J.(1991).A three-component conceptualization of organizational commitment. Human Resource Management Review, 1, 61-89.

Montague, A.(2013). Vocational and skill shortages in Vietnamese manufacturing and service sectors, and some plausible solutions. Asia Pacific Journal of Human Resources,51, 208-227.

Nguyen, D. T. N.,Teo, S. T.T., \& Ho, M.(2018). Development of human resource management in Vietnam: A semantic analysis.Asia Pacific Journal of Management,35, 241-284.

Nguyen, D.,Teo, S., \&Mylett, T. (2013).An exploration of the roles of HR departments in Vietnam.Journal of General Management,39, $83-113$.

Nguyen, T. N., Truong, Q., \&Buyens, D.(2011). Training and firm performance in economies in transition: A comparison between Vietnam and China. Asia Pacific Business Review, 17, 103-119.

OECD.(2010). Regional Integration: A Sectoral Approach. Southeast Asian Economic Outlook 2010. OECD Publishing. [Online] Available: https://www.oecd.org/countries/malaysia/46338931.pdf (February 25, 2019)

Petersen, M.(2009).Estimating standard errors in finance panel data sets: Comparing approaches.Review ofFinancial Studies, 22, 435-80.

Porter, M. (1990).The competitive advantage of nations.New York: The Free Press.

Quang, T., Le Chien, T., \&Rowley, C.(2008). The changing face of human resource management in Vietnam, in C. Rowley,\&Saaidah Abdul-Rahman (Eds.), The changing face of management in South East Asia. London: Routledge.

Rausch, E., \&Allio, R. J. (2005). Leadership development: teaching versus learning. Management Decision,43,107110788.

Saari, L. M., Johnson, T. R., McLaughlin, S. D., Zimmerle, D. M.(1988). A survey of management training and education practices in US companies. Personnel Psychology, 41, 731-743.

Schlenker, B.R., \& Leary, M. R.(1982). Social anxiety and self-presentation: A conceptualization model. Psychological bulletin, 92, 641-669.

Skylar Powell, K., \&Yalcin, S.(2010). Managerial training effectiveness: A meta-analysis 1952-2002. Personnel Review, 39, 227-241.

Swierczek, F. W., \&LanAnh, T. (2000). Management training needs: an assessment of Vietnam Saigon Plastics Association, in Truong Quang (Ed.), Vietnam: Challenges on the path to development(pp. 237-260). Bangkok: SAV-SOM Joint Publishing.

Thang, L. C., \&Quang, T.(2005).Antecedents and consequences of dimensions of human resource management practices in Vietnam. The International Journal of Human Resource Management, 16, 1830-1846.

Thang, N. N., \&Quang, T. (2007). International briefing 18: Training and development in Vietnam. International Journal of Training \& Development,11, 139-149.

Thang, N. N., \&Quang, T.(2011). The impact of training on firm performance in a transitional economy: Evidence from Vietnam. Research \& Practice in Human Resource Management,19, 11-26.

Thang, N.N., Quang, T., \&Buyens, D. (2011). Training and firm performance in economies in transition: A comparison between Vietnam and China. Asia Pacific Business Review,17, 103-119. 
The Economist.(2016). Good afternoon, Vietnam-Asia's next tiger. August 6. [Online] Available: https://www.economist.com/finance-and-economics/ 2016/08/06/good-afternoon-vietnam (March 2, 2019)

Truong, Q., van Der Heijden, B., \&Rowley, C.(2010). Globalization, Competitiveness and Human Resource Management in a Transitional Economy: The Case of Vietnam. International Journal of Business Studies, 18, 75-100.

US Department of State.(2015). 2015 Investment Climate Statement May 2015. Washington, DC:US Department of State.

Van Tuan, N., \&Nguyen, N.M. (2012).Effects of human resource management on business performance of small and medium size manufacturers in Hanoi - Vietnam. Australian Journal of Business and Management Research,2, 47-54.

Vietnam Ministry of Education and Training.(2014). The speech of Minister Pham Vu Luan at the TW8conference and the summary of educational activities in the period of 2012-2013.[Online] Available: http://www.moet.gov.vn/?page=1.10\&view=5508\&opt=brpage (Sept. 30, 2016).

Wilkinson, S.M., Gambles, M., \&Roberts, A.(2002). The essence of cancer care: the impact of training on nurses' ability to communicate effectively. Journal of advanced nursing, 40, 731-738.

Withers, L.A., \&Vernon, L.L.(2006).To err is human: Embarrassment, attachment, and communication apprehension. Personality and individual differences, 40, 99-110.

World Bank. 2013. Vietnam Development Report 2014: Skilling up Vietnam: Preparing theWorkforce for a Modern Market Economy. [Online] Available: http://documents.worldbank.org/curated/en/610301468176937722/pdf/829400AR0P13040Box0379879B00PU BLIC0.pdf (May 1, 2020).

World Bank.(2017). Taking Stock: An update on Vietnam's Recent Economic Developments, Special Focus: Towards a High-Quality Fiscal Consolidation. Washington DC: World Bank.

Zhu, Y., \&Verstraeten, M.(2013). Human resource management practices with Vietnamese characteristics: A study of managers' responses. Asia Pacific Journal of Human Resources,51, 152-174.

Zhu, Y.,Warner, M., \&Rowley, C.(2007). Human resource management with Asian characteristics: A hybrid people management system in East Asia. International Journal of Human Resource Management, 18, 745-768.

Zhu, Y.,Collins, N.,Webber, M., \&Benson, J. (2008). New forms of ownership and human resource practices in Vietnam. Human Resource Management,47, 157-175. 